\title{
Understanding innovative firms: an exploration of the use of USPTO data to identify innovative firms in small and medium sized economies
}

\author{
Hazel V J Moir ${ }^{*}$ \\ Adjunct Fellow, Centre for Policy Innovation, Australian National University, Canberra \\ Visiting Researcher, Department of Management and Marketing, University College Cork
}

\begin{abstract}
$\underline{\text { Abstract }}$
Although patent data have severe limitations as a measure of technological innovation (Griliches, 1990), patent data are frequently used for this purpose, providing potentially misleading analyses for policy makers. Kingston and Scally (2006) have shown that, for countries outside the NAFTA region, USPTO small enterprise patent data can provide useful insights into innovative activity in small and medium sized economies. This exploratory analysis investigates whether the Kingston/Scally analysis can be extended from inventors to assignee firms and considers the challenges of making this conversion. It also explores whether such a data series can be used to develop a typology of innovating firms which can be of interest for research and policy analysis purposes.
\end{abstract}

Australian inventor granted patent data from the USPTO BIB series from 1969 to 2010 is used to explore these issues. The focus is on patents assigned to firms. Converting these data to a set based on the residence of the firm owning the patent is tedious but not difficult. Nonetheless given the importance for policy purposes of focusing on innovative firms, it would be very useful if the USPTO were to include the assignee residence in the BIB dataset. More challenging, of course, is trying to ensure identification of all patents owned by any one firm. Typographical errors, keying errors and name changes make this a particularly tedious issue. It would be helpful if patent offices were to require (and use) a firm's company number as the principle identifier for data on a patent. In addition there are problems arising from changes in firm ownership and how these should be treated.

Three principal groupings of firms stand out - those which patent only once (the large majority); Silverbrook, with a portfolio of thousands of US patents; and some 400 firms with at least several US patents granted since 1995. A discussion of those firms with significant US patent holdings shows a variety of types of innovation leadership.

\footnotetext{
* The research for this paper was undertaken while the author was the recipient of an Australian government Endeavour Research Fellowship, held as a Visiting Researcher at the Department of Management and Marketing, University College Cork. Particular thanks are due to Dr Kevin Scally for his generosity in sharing data and expertise and providing a critical sounding board. Naturally errors and omissions are my own.
} 


\title{
Understanding innovative firms: an exploration of the use of USPTO data to identify innovative firms in small and medium sized economies.
}

\author{
Hazel V J Moir ${ }^{*}$
}

\section{The Issues}

The limitations of using patent data as a measure of technological innovation have long been known (Griliches, 1990). Despite this, patent data are frequently used in this way, providing potentially misleading analyses for policy makers. Kingston and Scally (2006) suggest that, for countries other than the USA, Canada and Mexico, USPTO small enterprise data can provide a potentially more valid approach to identifying genuine innovative activity in small and medium sized economies. This exploratory analysis, using data for Australia, investigates whether the Kingston/Scally analysis can be extended from inventors to assignee firms and considers the challenges of making this conversion. It also explores whether such a data set can be used to develop insights into innovating firms which can be of interest for research and policy analysis purposes.

The paper starts with a discussion of a range of issues in converting these data from an inventor basis to a firm ownership basis - a perspective that is more useful for innovation policy purposes (Section 2). This discussion identifies some aspects of patent data that could be improved to increase their value to policy makers. In Section 3 the characteristics of Australian firms patenting in the USA are explored, suggesting considerable differences in firms' use and experience of US patenting. This discussion identifies further data issues in analysing the patent data on a firm basis for a particular country.

Given these data issues is it possible to use these data for any meaningful analysis of innovative firms in a particular economy? This question is addressed in Section 4. A variety of types of firms are frequent US patenters - some are examples of technology spinouts from scientific research; others began as foreign subsidiaries; some have been taken over by overseas companies; and some work in product areas not generally considered to be very high technology. Overall however, the insights that can be gained from patent data alone are limited. Conclusions are presented in Section 5.

\section{Methodology}

As the largest single market in the world, data on patent activity in the USA by innovating firms should, for many countries, provide useful information into domestic firms with globally-directed innovative activity. ${ }^{1} \mathrm{~A}$ further reason for using data for the USA is that, of

\footnotetext{
* All URLs cited in this paper were accessed during the period between May and July 2011, unless otherwise indicated.

${ }^{1}$ That is, the patent data act as a proxy for selling into the USA, not for inventiveness. The low standard of the US patent inventive step is well documented, so US patents cannot in general be taken as a proxy for inventiveness (see e.g. Jaffe \& Lerner, 2004, Lunney, 2001).
} 
all major national patent offices, the United States Patent and Trademark Office (USPTO) provides the most accessible data for research purposes. The one downside of this dataset is that data on the geographic 'home' of granted patents is provided on the basis of the inventor not the owner of the patent.

The initial dataset, extracted from the USPTO "Patents BIB" series, ${ }^{2}$ consists of all patents granted from 1969 to 2010 where any inventor reports Australia as their country of residence. This dataset of 23,833 cases, ${ }^{3}$ was reduced to the sub-set where the patent was assigned to any organization or firm, excluding non-profit entities (16,545 cases). Data on the country of the assignee firm were then added to the dataset.

\subsection{Identifying all patents owned by each firm}

Following this, substantial work was undertaken to identify all the US patents owned by a single firm. Small differences in how a company name is entered, together with typographical errors, can mean considerable work in checking company identity. Because there is only limited bibliographic information on the scanned record, sometimes this information is inadequate to identify if, for example, two particular patents are owned by the same company or by different companies with very similar names. Information used in this matching process included inventor names, residence of assignee in the USPTO records, similarity in patent titles, independent information from the ASIC company search website, ${ }^{4}$ information on companies listed on the Australian Securities Exchange, ${ }^{5}$ ceased or suspended companies from the deListed website ${ }^{6}$ and general web searches. ${ }^{7}$

In many dealings with governments firms are required to provide a company registration number or other formal identifier. If such a requirement were added to the patent monopoly system, researchers could more readily analyse firm ownership of patents. This could also provide a very valuable additional source of data on innovative firms as national statistical offices can use such identifiers to cross-link firm data acquired through different surveys. This would provide valuable insights into the use of the patenting system by innovative firms.

A further challenge is that companies can take many separate corporate identities, even where each subsidiary is 100 percent owned. These complex corporate structures provide

\footnotetext{
2 http://www.uspto.gov/products/catalog/patent_products/page6.jsp\#heading-5 ("Patents BIB: Selected Bibliographic Information from US Patent Grant Publications and Patent Application Publications 1969 to Present"). The version used provides data on all grants to the end of 2010.

${ }^{3}$ The initial dataset was 23,836 cases but two very old cases were discarded (one filed in 1930 and one in 1938). A third case was deleted as it involved an Austrian inventor and assignee, misclassified as AU not AT.

${ }^{4}$ The Australian Securities \& Investments Commission (ASIC) maintains the official register of all Australian company names and this can be searched at http://www.search.asic.gov.au/gns001.html .

${ }^{5}$ The Australian Securities Exchange (ASX) website provides a useful look-up service for listed companies at http://www.asx.com.au/research/company-research.htm .

6 "deListed provides updates and information on failed companies including those in external administration and companies suspended from ASX, NZX, NSX and BSX. It also has all historical name changes and delistings for these exchanges and carries administrators/liquidators declarations for Australian companies for tax purposes" (http://www.delisted.com.au/aboutus.aspx).

${ }^{7}$ The latter are considerably hampered by many aggregator companies selling company information services. Annoyingly, most such companies provide no information beyond the company name, so they impede rather than facilitate web search. For smaller companies this can mean considerable difficulty in actually finding the company website, and there are some challenges even for some larger companies.
} 
major legal and financial benefits to owners. But such legal fictions are irrelevant where the issue of interest is patent ownership and the impact of ownership on firm behaviour. There is thus a need to delve behind the 'corporate veil' to re-assign patents owned by separate elements within a corporate grouping to the current final owner. This raises challenges - at what point in time should such ownership be determined? One of the alleged purposes of the patent system is to facilitate trade in technology, often through the purchase of innovative start-up companies. In a sense therefore re-assignment to the new owner merely follows the original intent of the development of the new technology - to acquire a financial return through selling the company. Here efforts have been made to reassign ownership to the current owner. ${ }^{8}$

\subsection{Determining firm 'nationality'}

The next issue is determining when company residence can be classified as Australian. For a large majority of companies this is straightforward as all their patents are linked to an assignee company resident in Australia. But 1,187 firms assigned all patents in the dataset to entities resident only outside Australia and 97 other firms assigned some of their patents to entities outside Australia. The official USPTO definition of inventor residence is residence at grant, which could be seven or more years after the application is filed. ${ }^{9}$ In practice at least some of the inventor residence data is collected at the time of application. ${ }^{10}$

If inventor residence data were consistently as at grant, there is substantial opportunity for the inventor to move between invention and grant. Using the somewhat crude measure of year of issue less year of filing, some 18 percent of patents were granted within a year and a further 35 percent in the second year - plenty of opportunity for the inventor to change residence. The data in Table 1 show that where there is any overseas assignment by the firm a higher proportion of patents are granted after a more substantial time lag - 19 percent are granted after a delay of five or more years (compared to 13 percent among firms where all assignment is to Australian entities).

Table 1 Assignment of patents by gap between years of application and grant

\begin{tabular}{|l|c|c|c|c|}
\hline & \multicolumn{4}{|c|}{ Assignment of US patents with Australian inventors } \\
\hline $\begin{array}{l}\text { Difference between } \\
\text { patent issue year } \\
\text { and file year }\end{array}$ & $\begin{array}{c}\text { All assigned } \\
\text { overseas }\end{array}$ & $\begin{array}{c}\text { Some } \\
\text { assigned } \\
\text { overseas }\end{array}$ & $\begin{array}{c}\text { Any assigned } \\
\text { overseas }\end{array}$ & $\begin{array}{c}\text { All } \\
\text { assigned in } \\
\text { Australia }\end{array}$ \\
\hline Same year & $1 \%$ & $0 \%$ & $1 \%$ & $1 \%$ \\
\hline 1 year & $14 \%$ & $14 \%$ & $14 \%$ & $18 \%$ \\
\hline 2 years & $32 \%$ & $31 \%$ & $32 \%$ & $37 \%$ \\
\hline 3 years & $21 \%$ & $22 \%$ & $21 \%$ & $22 \%$ \\
\hline 4 years & $14 \%$ & $14 \%$ & $14 \%$ & $11 \%$ \\
\hline 5+ years & $19 \%$ & $19 \%$ & $19 \%$ & $13 \%$ \\
\hline Total & $100 \%$ & $100 \%$ & $100 \%$ & $100 \%$ \\
\hline $\mathbf{N}$ & 3,521 & 2,101 & 5,622 & 10,923 \\
\hline
\end{tabular}

\footnotetext{
${ }^{8}$ Research funds did not permit access to commercial company databases, so this effort is incomplete.

9 "Inventor Country (ICN): This field contains the country of residence of the inventor at the time of patent issue." (http://www.uspto.gov/patft/help/helpflds.htm\#Inventor_Country).

10 Personal communication from USPTO.
} 
From a policy perspective inventor residence at filing would be more useful - the file year reflects both the closest point to actual inventive activity and the time when the initial business decision to seek a patent monopoly is made. Inventor residence at time of grant might be useful in the grant year, but such data will age in a way that file year data will not.

The unknown mixture of timing for inventor residence complicates assessing the implications of Australian-invented US patents assigned to non-Australian entities. Where these patents involve a delayed grant, and the applicant has provided inventor residence at time of grant, then the patent may have nothing to do with Australia, in terms of the location of R\&D activity.

On the other hand, the inventive activity may have occurred in Australia but the firm may have a policy of assigning all patents to corporate headquarters. Of the 477 firms in this category with two or more US patents, all but 32 assign all patents to a single country. Only a few companies assign patents to entities in more than one country, for example, Nokia. In some cases assignment to more than one country is simply a product of subsequent corporate take-overs - for example BASF and Bayer. Another reason for mixed assignment is joint ownership, where $\mathrm{R} \& \mathrm{D}$ was undertaken cooperatively, e.g. some Biogen and Celerity patents.

Within the set of 1,147 firms with 2 or more patents, and at least one assigned to an Australian-based entity there were 97 cases, mostly larger enterprises, where assignment had mixed nationality. Where a firm has multiple patents and mixed nationality assignment, there is a challenge in assigning an overall nationality to the firm. Here this was done on the basis of the country to which patents are most frequently assigned, except where there was clear alternative information about company headquarters. In some cases determining companies' nationality is uncertain - for example if only two US patents are owned and one is assigned in Australia and one overseas.

\section{Mixed assignment by overseas companies}

Twenty-four overseas-based companies with over ten Australian-invented US patents assign only some of these patents to Australian entities (Table 2). Generally the large majority are assigned back to the home base, with the apparent exception of Alcatel simply being due to takeover activity. The interesting cases are those with a smaller share of patents assigned overseas. For example, Ishikawajima-Harima Heavy Industries partnered with Bluescope Steel for all 119 patents, all of which are jointly owned, hence the 50 percent assignment to Australian entities. Schefenacker Vision, with only 8 percent of patents assigned back to the USA, has both a manufacturing and an R\&D facility in South Australia. The original Australian company (Rainsford Metal Products Pty Ltd) was acquired by the British Britax International and subsequently became part of US-based Schefenacker Vision. The continued Australian presence may be partly reliant on government adjustment assistance to the automotive industry and to other programs such as the Export Facilitation Scheme and the R\&D tax concession. 
Table 2: Overseas-based firms with over 10 US patents and assignment to Australian entities

\begin{tabular}{|l|c|c|c|c|c|}
\hline Company & $\begin{array}{c}\text { Company } \\
\text { head- } \\
\text { quarters }\end{array}$ & $\begin{array}{c}\text { Number } \\
\text { US } \\
\text { patents }\end{array}$ & $\begin{array}{c}\text { \% } \\
\text { assigned } \\
\text { overseas }\end{array}$ & $\begin{array}{c}\text { Major } \\
\text { assignee } \\
\text { country }\end{array}$ & $\begin{array}{c}\text { \% to major } \\
\text { assignee } \\
\text { country }\end{array}$ \\
\hline Robert Bosch & DE & 29 & $97 \%$ & DE & $96 \%$ \\
\hline Siemens & US & 28 & $96 \%$ & US & $52 \%$ \\
\hline Massey-Ferguson & AN & 23 & $96 \%$ & AN & $100 \%$ \\
\hline Lubrizol & US & 12 & $96 \%$ & US & $100 \%$ \\
\hline Nalco & US & 16 & $94 \%$ & US & $100 \%$ \\
\hline Borg Warner & US & 15 & $93 \%$ & US & $100 \%$ \\
\hline Canon & JP & 376 & $92 \%$ & JP & $100 \%$ \\
\hline Chiron & US & 20 & $90 \%$ & US & $100 \%$ \\
\hline Alcatel & FR & 103 & $89 \%$ & US & $51 \%$ \\
\hline Du Pont & US & 28 & $89 \%$ & US & $92 \%$ \\
\hline Illinois Tool Works & US & 19 & $89 \%$ & US & $100 \%$ \\
\hline Dow Corning & US & 11 & $82 \%$ & US & $100 \%$ \\
\hline Smith \& Nephew & US & 11 & $82 \%$ & US & $100 \%$ \\
\hline Cisco & US & 119 & $81 \%$ & US & $100 \%$ \\
\hline Ericsson & SE & 63 & $76 \%$ & SE & $100 \%$ \\
\hline Sealed Air & US & 12 & $75 \%$ & US & $56 \%$ \\
\hline Nortel & CA & 11 & $73 \%$ & CA & $100 \%$ \\
\hline Johnson \& Johnson & US & 32 & $72 \%$ & US & $96 \%$ \\
\hline ABB & CH & 15 & $70 \%$ & CH & $76 \%$ \\
\hline Sandvik & SE & 16 & $69 \%$ & SE & $82 \%$ \\
\hline Ishikawajima Harima & JP/AU & 51 & $50 \%$ & JP & $100 \%$ \\
\hline Glaxo & GB & 17 & $47 \%$ & US & $63 \%$ \\
\hline Rib Loc & HK & 16 & $38 \%$ & HK & $100 \%$ \\
\hline Schefenacker Vision & US & 37 & $8 \%$ & US & $100 \%$ \\
\hline Nos: & US A & & & \\
\hline
\end{tabular}

Notes: See Appendix for a list of patent country codes.

Glaxo's assignment of nine of its 17 patents to an Australian entity stands in sharp contrast to other major pharmaceutical companies which assign all their Australian-invented US patents to their home base (Novartis, Pfizer, Hoffmann-La Roche, for example). Despite extensive Australian government support to the pharmaceutical industry there are no major players undertaking R\&D in and assigning US patents to Australian entities, except for a small number of indigenous success stories which are discussed below (Section 3.4).

Rib Loc is an entirely different story - this is an Australian pipe manufacturer which became a target of interest to a Hong Kong based investment company, Chevalier, who launched a take-over bid in 2004. Rib Loc is now one of its brands, but remains based in Australia. ${ }^{11}$

\section{Mixed assignment by Australian companies}

On the basis of the share of patents assigned to Australian entities 11 companies with mixed assignment of ownership and more than ten US patents were initially classified as 11 See http://www.chevalier.com/english/contentpage.asp?id=1170 and http://www.theage.com.au/articles/
2004/02/25/1077676832013.html?from=storyrhs 
Australian-based (Table 3). On further scrutiny it becomes clear that most are in fact headquartered overseas. US-based Agilent acquired Varian in $2010^{12}$ and most of the patents in the dataset are owned by Varian entities either in the USA or in Australia. ${ }^{13}$ Dilithium and the Cook Group are also US-based while the Leica brand covers three companies based in Germany and Switzerland. Carl Zeiss Vision is also US based and owns, among other companies, Sola Lenses. This was originally a leading edge Australian contact lense manufacturer, Sola standing for Scientific Optical Laboratories of Australia, incorporated in 1960 in Adelaide. It was acquired by Pilkington PLC and then spun out in 1993 before being acquired by Carl Zeiss in 2004. ${ }^{14}$ All but three of Carl Zeiss' 49 US patents are assigned to Sola International Holdings Ltd. While Australian production operations have been wound back, Sola still undertakes at least some R\&D in Adelaide. ${ }^{15}$

Table 3: 'Australian' firms with over 10 US patents, some assigned overseas

\begin{tabular}{|l|c|c|c|c|c|}
\hline Company & $\begin{array}{c}\text { Company } \\
\text { nationality }\end{array}$ & $\begin{array}{c}\text { Number } \\
\text { of US } \\
\text { patents }\end{array}$ & $\begin{array}{c}\% \\
\text { assigned } \\
\text { overseas }\end{array}$ & $\begin{array}{c}\text { Major } \\
\text { assignee } \\
\text { country }\end{array}$ & $\begin{array}{c}\% \text { to major } \\
\text { assignee } \\
\text { country }\end{array}$ \\
\hline Agilent (Varian) & US & 57 & $46 \%$ & US & $100 \%$ \\
\hline James Hardie & $\mathrm{AU} \rightarrow \mathrm{NL} \rightarrow \mathrm{IE}$ & 44 & $41 \%$ & $\mathrm{NL}$ & $61 \%$ \\
\hline Leica & $\mathrm{DE} / \mathrm{CH}$ & 11 & $36 \%$ & $\mathrm{CH}$ & $75 \%$ \\
\hline Dilithium & $\mathrm{US}$ & 22 & $27 \%$ & US & $100 \%$ \\
\hline Cook Group & $\mathrm{US}$ & 31 & $26 \%$ & US & $63 \%$ \\
\hline BOC gases & $\mathrm{GB} \rightarrow \mathrm{DE}$ & 42 & $21 \%$ & US & $89 \%$ \\
\hline Orica & $\mathrm{GB} \rightarrow \mathrm{AU}$ & 265 & $12 \%$ & $\mathrm{~GB}$ & $100 \%$ \\
\hline Memtec & $\mathrm{AU} \rightarrow \mathrm{US}$ & 34 & $12 \%$ & $\mathrm{US}$ & $100 \%$ \\
\hline Carl Zeiss Vision (Sola) & $\mathrm{US}$ & 49 & $6 \%$ & US & $100 \%$ \\
\hline Bluescope Steel & $\mathrm{AU}$ & 27 & $4 \%$ & $\mathrm{PA}$ & $100 \%$ \\
\hline BHP & $\mathrm{AU}$ & 166 & $1 \%$ & US & $50 \%$ \\
\hline
\end{tabular}

Four of the 11 'Australian' companies changed 'residence' over the period. Two did so because of take-over activity (BOC, Memtec). One company became Australian due to divestment by its overseas parent (Orica). A fourth company which changed 'residence' did so for strategic reasons at a time of major legal dispute over occupational health liabilities (James Hardie). What impact will these changes have on the apparent residence of patent ownership? For Orica most patents were assigned to the Australian-based entity prior to this corporate change, so there is likely to be a small shift to 100 per cent assignment to Australia. Before James Hardie's corporate move all US patents were assigned to an

\footnotetext{
${ }^{12} \mathrm{http}: / / \mathrm{www}$. home.agilent.com/agilent/home.jspx?cc=US\&lc=eng

13 Varian was founded in the late 1940s by scientists associated with Stanford University. Varian now employs some 5,500 people in oncology treatment equipment, $\mathrm{x}$-ray tubes and the use of x-rays for security screening. Within Australia Varian focuses on oncology-related measuring equipment (http://www.varian.com/us/corporate/our_company/company_facts_history.html).

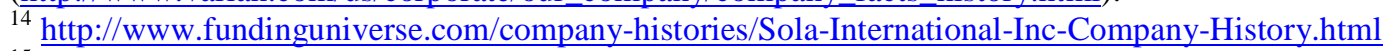

15 A press release of 5 March 2009 refers to a grant "through the South Australian Innovation and Investment Fund which will be used to expand operations in the cutting-edge free-form surfacing division" (see http://www.vision.zeiss.com.au/C12571C3003240A9/EmbedTitelIntern/PR_CZV_Future/\$File/CZV_Prepare s_Way_to_Future.pdf).
} 
Australian entity. Since 2005 all have been assigned to Ireland, and in between there was mixed assignment to Australia, the Netherlands and Ireland. It seems likely that all future US patents will be assigned to the new Irish headquarters. Before being taken over in 2006 by the German Linde group, most of BOC's 42 Australian-invented US patents were assigned to the Australian subsidiary, with the bulk of those assigned overseas assigned to a US subsidiary. There is as yet no clear indication of what Linde's patent assignment policy will be. Memtec began assigning patents to its new US subsidiary in 1995, and was subsequently purchased by US-based Pall Corporation. No Australian-invented US patents have been granted from filings since mid 1996 suggesting that the Sydney R\&D expertise has either moved to the new US venue or has been disbanded.

The remaining two companies are, like Orica, Australian-based. But the proportion of their patents assigned overseas is very small. Only one of Bluescope's 27 patents is assigned overseas - to Panama - and only two of BHP's 166 patents are assigned overseas.

Overall 35 percent of firms in the dataset assign all their Australian-invented US patents to non-Australian firms and a further 3 percent of firms assign some of their patents overseas. The dominant countries where Australian-invented patents are assigned overseas are the USA, the UK and Germany. A small point of interest is that there are 13 tax haven countries among those where these patents are assigned, though the number of patents involved is small (51). But clearly the majority of Australian-invented US patents are assigned to Australian entities (Figure 1).

Overseas assignment of patents thus means that close to 30 per cent of Australian-invented US patents are not owned by Australian-based entities. Doubtless this is offset to some extent by US patents invented by residents of other countries but owned by Australian firms. It does, however, seem likely that the actual R\&D effort for many of these overseas owned patents occurred in Australia.

Figure 1: Assignment of US patents owned by firms and invented by Australian residents, 1970-2010

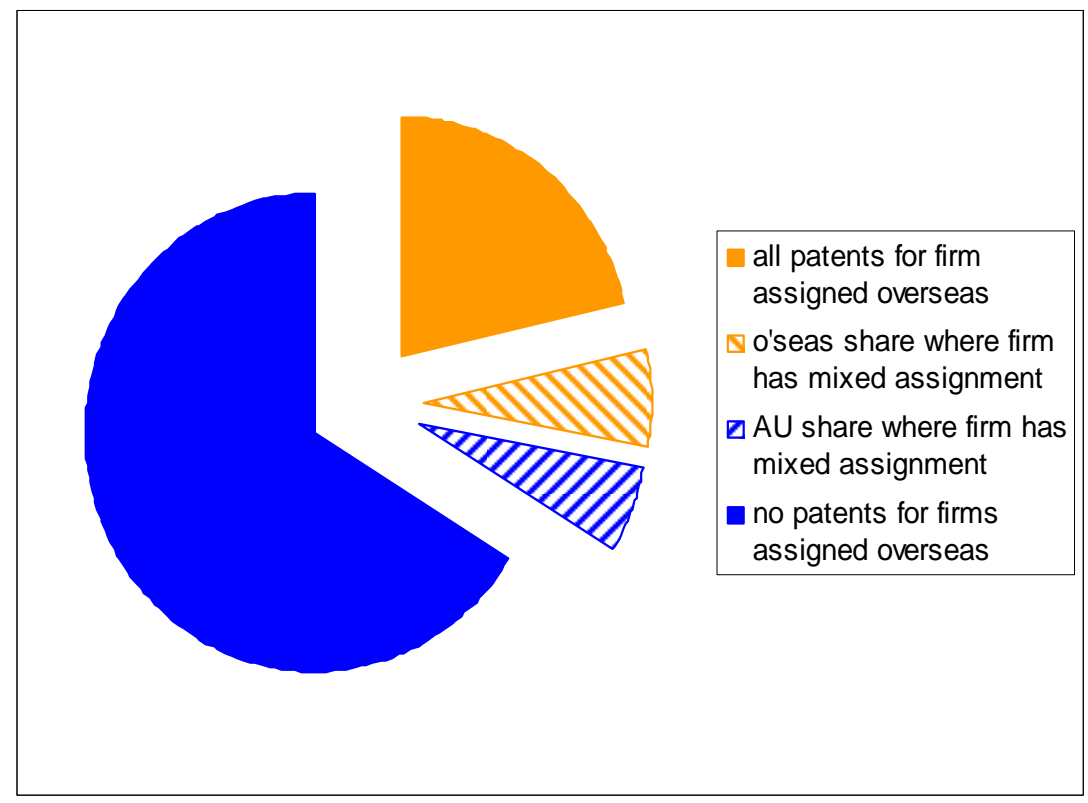




\section{Basic characteristics of the dataset}

A number of characteristics of firms in this dataset can be explored to understand what types of firms are patenting in this major overseas market: number of US patents owned, the time period in which such patenting activity is carried out, whether the firms claim the small entity fee, whether patents are assigned to any entities resident outside Australia and the technology field in which they operate. Most of this analysis is based on the dataset of 13,024 patents owned by 3,401 firms where at least one patent held by a firm is assigned to an Australian entity.

\subsection{Volume of patents owned}

It is well known that both patent ownership and returns from patent ownership are highly skewed distributions. The 13,024 patents in the dataset are owned by 3,401 firms, of which 2,256 have only one US patent each during the 42 year period covered by the data. Within the remaining 1,145 firms patent ownership is highly skewed - at one extreme 548 firms have only 2 patents. At the other extreme one firm, Silverbrook Research Pty Ltd owns 3,666 US patents filed between 1998 and 2010. Figure 2 shows the distribution of patents owned by all 3,401 firms, while Figure 3 shows the distribution excluding both Silverbrook and all firms with 10 or fewer patents. Figure 3 thus focuses on 100 of the firms in the extreme bottom left corner of Figure 2.

Figure 2:

Australian firms owning US patents: 1969-2010, by US patents held.

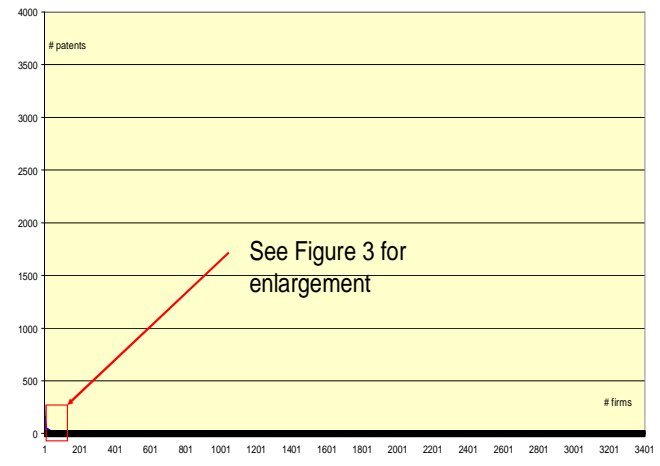

Figure 3:

Australian firms with 51-400 US patents owning US patents: 1969-2010.

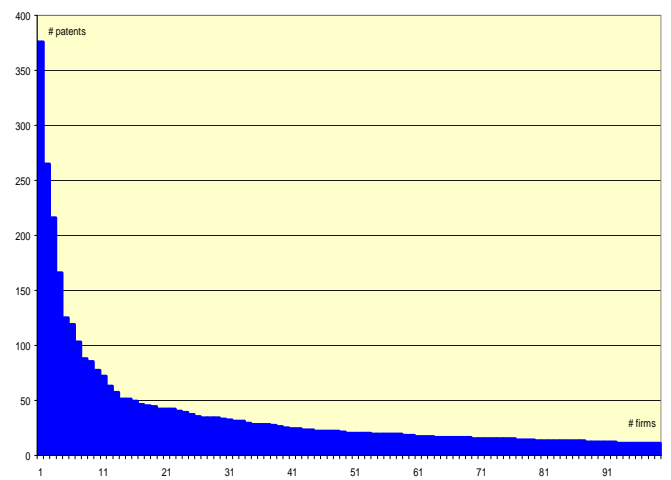

An alternative way of looking at these data is to consider the number of firms with different levels of US patenting activity (Figure 4). While Silverbrook dominates the number of patents held, it is the sole firm patenting at this volume. The next most prolific patenter holds 376 US patents. Indeed there are only 15 other firms with more than 50 US patent grants. ${ }^{16}$ Of these 15 firms six assign at least some of their Australian-invented US patents to entities resident outside Australia. The dataset is dominated by firms who have only a single experience of patenting in the USA - 66 percent of the firms in the dataset.

\footnotetext{
${ }^{16}$ Canon, Orica, Resmed, BHP, Orbital, Cisco, Technological Resources, Cochlear, Aristocrat, Rio Tinto, Ericsson, Alcatel, Agilent, Bishop and Ishikawajima Harima.
} 
A further 22 percent have only 2 or 3 US patents, and just 7 percent ( 224 firms) have six or more US patents.

Figure 4: Australian-based firms, total number of US patents held.

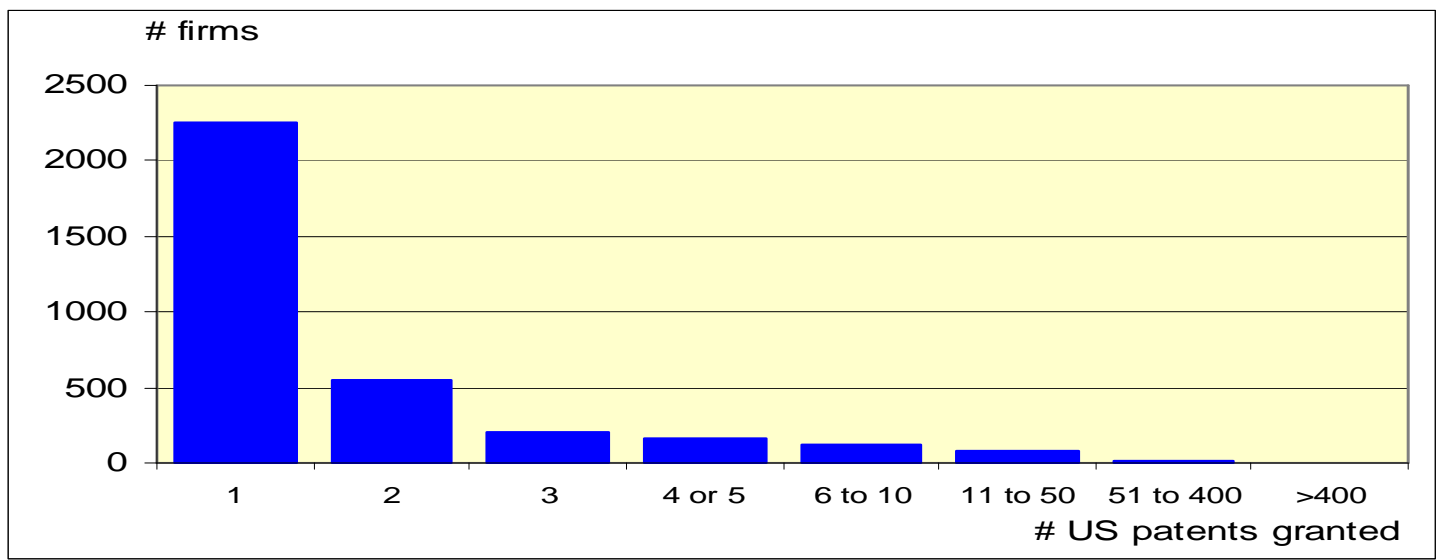

\subsection{Patenting behaviour over time}

Patenting behaviour changed significantly during the period 1969 to 2008 (Blind et al., 2003, Hall, 2005, Kim \& Marschke, 2004, Kortum \& Lerner, 1999). This 'explosion' of patenting can be clearly seen in Figure 5 - after a long period of only gradual increase, there is a significant year-on-year increase from the early 1990s. The apparent decrease since 2004-05 is due to the fact that these are file year data not grant year data - it can take a number of years for a cohort of applications to be fully processed. ${ }^{17}$ For example, if Silverbrook's pending applications are all be granted (as was the case for filings in $1998,1999,2000$ and 2002) then the series shows no general pattern of decline, as shown in Figure 6 below.

These data also show the extraordinary dominance of a single firm on the series in recent years. Silverbrook first applied for US patents in 1998, and in all but two years since then has contributed at least 27 percent of all US patents held by Australian-based firms. This figure rises to 62 percent in 2002 when 731 Silverbrook applications were granted. If Silverbrook had not emerged, the series would peak earlier (2001-02 rather than in 2004) but at a lower level. The pattern of an increasing number of applications for US patents over time, followed by a fall-off, is clear for firms operating at all levels of US patenting activity, from firms who only ever obtain one patent to those with hundreds.

\footnotetext{
${ }^{17}$ The discussion below on Silverbrook shows the long delays that can occur in fully processing a cohort of patent applications (see Table 7).
} 
Figure 5: US patents granted to Australian-based firms by 31 December 2010, by filing year (1970 to 2008) and total number of US patents held by firm.

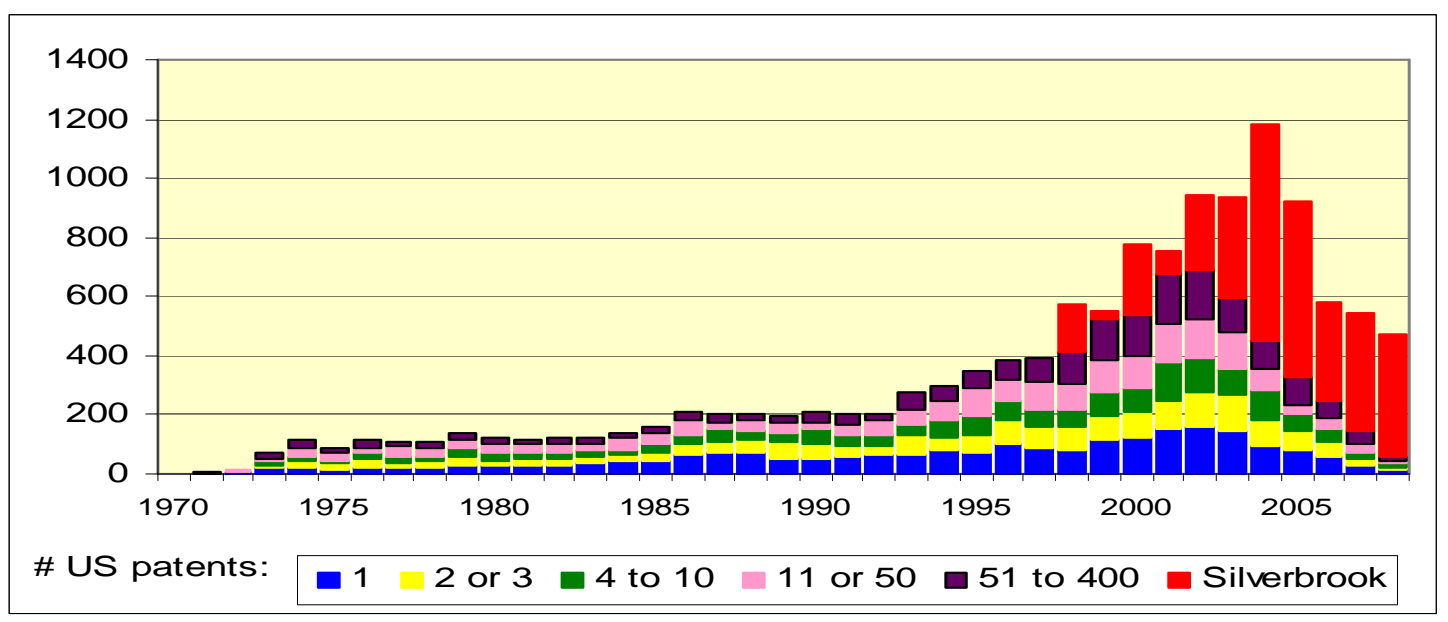

Figure 6: US patents granted to Australian-based firms by 31 December 2010, by filing year (1970 to 2008), assuming all pending Silverbrook patents granted.

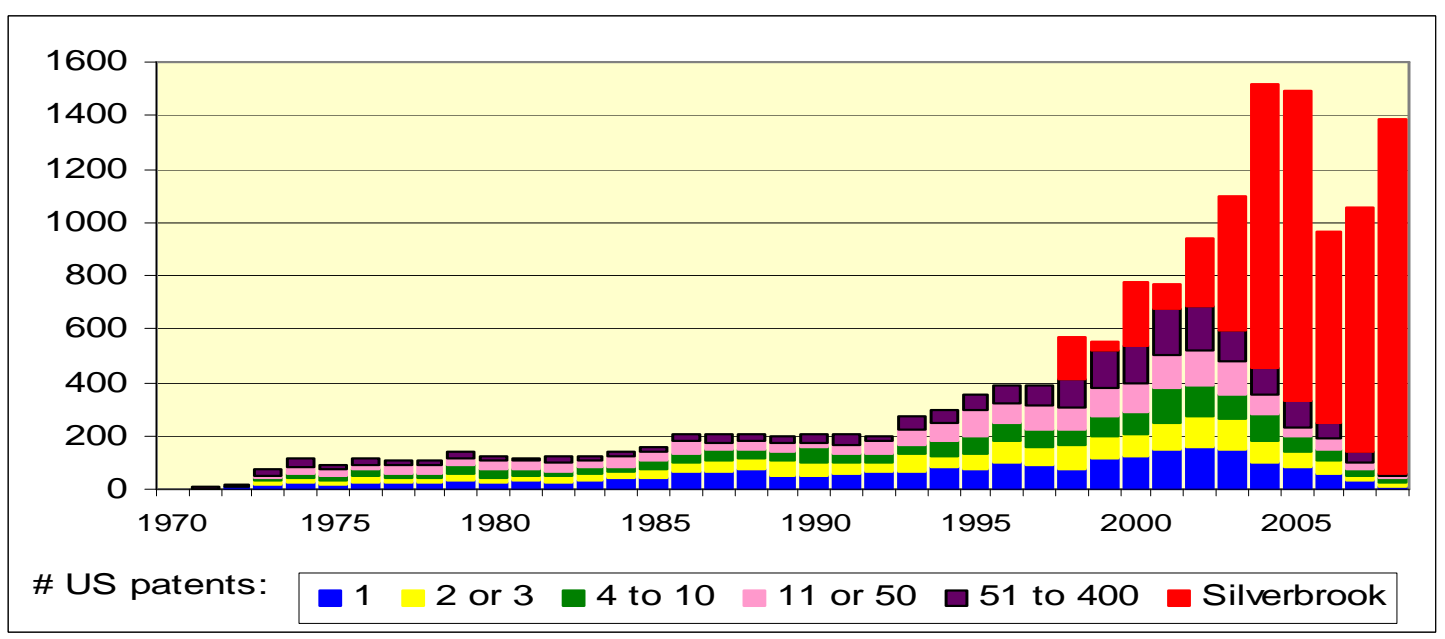

Silverbrook illustrates the care that must be taken in using patent statistics. While such strategic patenting behaviour is not unusual in the complex technology areas, especially electronics, if such firms are rare in an economy (as is the case in Australia) then simple use of overall data can be misleading. Gans and Hayes, for example, use US patent grants as their key measure of 'national' innovative output for Australia. While they note that Australia's increased technological specialisation is largely due to Silverbrook (Gans \& Hayes, 2009: 11), there is little discussion of the impact of Silverbrook on the volume of US patents in the period since 1998. This example also raises the question of whether the story told by patent statistics might differ if data on the relatively small number of very frequent users of the patent system were analysed separately. 


\subsection{Firm size}

In 1984 the US Congress introduced lower patent application and renewal fees for small enterprises and those with non-profit-making status. To be eligible for this reduced fee a profit-making firm has to have fewer than 500 employees. If the small enterprise (SE) fee is falsely claimed, the patent becomes invalid, so there is a strong incentive not to misclaim this benefit. Data on SE fees by patent number were provided by the USPTO to Kevin Scally and through him to the author. These data are not available for all cases in the USPTO BIB series. Among the 2,256 firms with only one US patent, 979 claimed the SE fee and 364 are known to have paid the full fee. This leaves 913 such firms where fee data do not indicate firm size. About a third of these relate to patents filed before the end of 1984, when the SE fee was introduced (331 of 913).

The default assignment option for these single patent missing data firms is that they are small enterprises - they are resident in Australia, which has a relatively small manufacturing base and where larger firms tend to be well-known names. Indeed the Australian definition of a small business is one which employs fewer than 20 people ${ }^{18}$ so a firm employing 500 or more would be seen as quite large. For all these single patent missing cases assignee names were scrutinised and large enterprise status was assigned in only 11 cases. ${ }^{19}$ Following this, 83 percent of firms with only one US patent are classified as small. Among the 364 firms not claiming the SE fee, scrutiny of their names suggests that in fact as few as a dozen might have 500 or more employees. But as Kingston and Scally demonstrated (2006: pp14-16), small firms do not always claim the SE fee, so many of these

\section{Box 1: Mixed SE fee strategy}

Among the 1,147 firms with more than one US patent, 208 only sometimes claimed the SE fee. In 12 cases this appears to be either an error, or a case of firm growth. The remaining 196 constitute 47 percent of small firms with two or more US patents. The practice of only sometimes claiming the SE fee is clearly common. 364 firms may in fact be small firms.

For firms with two or more patents where size data were missing each firm name was searched on the ASIC, ASX and deListed websites and in the Encyclopedia of Australian Science which provides useful basic information on many Australian organisations, including companies. ${ }^{20} \mathrm{~A}$ general web search was also done. If none of these sources identified the company, then it was given the default value of small enterprise. If a company website was found this was searched for data on company size. If no clear evidence of size was found the company was designated as small. There were 270 cases where this procedure was followed to determine likely firm size. This intensive process also identified further firms with common ownership.

\footnotetext{
${ }^{18}$ http://www.abs.gov.au/AUSSTATS/abs@.nsf/Lookup/1321.0Glossary12001?OpenDocument

19 John Fairfax \& Sons Ltd., Brambles Holdings Ltd., Bowater-Scott Corporation Ltd., Burns, Philp \& Co. Ltd., Ok Tedi Mining Ltd., Pak-Poy \& Kneebone Pty Ltd., Broken Hill Associated, Palmer Tube Mills (Aust) Pty Ltd., North Broken Hill Ltd., Hoover (Australia) Pty Ltd., and the strangely named "Council of the Science" (likely a coding error, but the patent is jointly owned with the University of Adelaide, which although non-profit would be a large employer).

${ }^{20}$ The Encyclopedia of Australian Science is at http://www.eoas.info/browsea_corporatebodies.htm
} 
Because of the very high definition of 'small' the dataset is dominated by 'small' firms overall 78 percent of firms. The proportion of 'small' firms falls over time: among firms who last filed a granted US application in 1984 or earlier, fully 93 percent were small (Table 4). However, among firms which last filed a granted patent application in 1995 or later only 72 percent were classed as small. ${ }^{21}$

Another clear pattern in regard to firm size is the prevalence of small firms among those with fewer patents. Of those firms with only one US patent, 83 percent are small. By the time patent ownership reaches between six and ten US patents, only 56 percent of firms are small. For those owning 50 or more US patents, only 13 percent are small. The most voluminous US patenter in the dataset, Silverbrook Research Pty Ltd, now has more than 500 employees. This pattern of larger firms dominating the patent system - owning the largest volume of patents and patenting more intensively is well documented elsewhere. ${ }^{22}$

Table 4 Firms size by year last patented, and number of US patents granted

\begin{tabular}{|c|c|c|c|c|c|}
\hline & \multicolumn{3}{|c|}{ Firm Size } & \multirow{3}{*}{ Total } & \multirow{3}{*}{$\%$ small } \\
\hline & Small & Large & Dead & & \\
\hline \multicolumn{4}{|c|}{ Year of last filed patent ${ }^{*}$} & & \\
\hline 1969 to 1984 & 399 & 25 & 4 & 428 & $93 \%$ \\
\hline 1985 to 1994 & 744 & 101 & 5 & 850 & $88 \%$ \\
\hline 1995 to 2010 & 1519 & 604 & 0 & 2123 & $72 \%$ \\
\hline Total & 2662 & 730 & 9 & 3401 & $78 \%$ \\
\hline \multicolumn{6}{|l|}{ \# US patents } \\
\hline 1 & 1881 & 375 & 0 & 2556 & $83 \%$ \\
\hline 2 & 415 & 129 & 4 & 548 & $76 \%$ \\
\hline 3 & 150 & 57 & 1 & 208 & $72 \%$ \\
\hline 4 or 5 & 117 & 47 & 1 & 165 & $71 \%$ \\
\hline 6 to 10 & 68 & 53 & 0 & 121 & $56 \%$ \\
\hline 11 to 50 & 30 & 54 & 3 & 87 & $34 \%$ \\
\hline 51 to 400 & 1 & 14 & 0 & 15 & $7 \%$ \\
\hline
\end{tabular}

These time periods are selected to separate the period before the introduction of the SE fee, and to allow a full decade of completed filing cohorts for the last period - although this period looks longer, there are long delays in processing some patents and for most of the later file years only a small proportion of filings have completed the examination process.

\footnotetext{
${ }^{21}$ While missing firm size data are more prevalent in the earliest period, this pattern seems unlikely to be attributable simply to the assignment process for missing data, as it is consistent with the general pattern of falling share of smaller firms among patent applicants.

${ }^{22}$ Blind and colleagues usefully summarise the evidence refuting the theoretical position that patents should be more important for small than for large firms before adding their own data showing that patenting is more important and frequent among large than among smaller firms in Germany (Blind et al., 2006: 661-2).
} 


\subsection{Technology field}

There are well-known challenges in identifying the technology field of patents, particularly if one is interested in the industrial use of the technology (Griliches, 1990). Nonetheless it is of interest to review at least the broad technology fields in which Australian owned US patents are found. The focus is on the technology in which the firm is operating. If all patents owned by a firm are classified in a single category (mechanical, electrical or chemical) then the firm is classified in that technology field. ${ }^{23}$ However, if the firm holds patents across more than one category it is classified as 'mixed' in terms of its technology field. Over time the proportion of firms patenting in the mechanical arena has declined, though this is still the dominant group of firms (Table 5). The shares of firms patenting in both the chemical and electrical arenas have increased, in both cases most significantly in the period since 1995. The increase over time in those firms patenting across more than one broad technology field occurred between 1984 and 1994 in contrast to the increase in chemical and electronic patenting after 1994.

Table 5: Firms' field of technology by period last patented

\begin{tabular}{|l|r|r|r|r|r|r|r|r|}
\hline \multirow{2}{*}{$\begin{array}{l}\text { Technology } \\
\text { field of firm }\end{array}$} & \multicolumn{8}{|c|}{ Year last granted patent filed } \\
\cline { 2 - 8 } & \multicolumn{2}{|c|}{ to end 1984 } & $\mathbf{1 9 8 5}-1994$ & \multicolumn{1}{|c|}{$\mathbf{1 9 9 5}$ on } & \multicolumn{2}{|c|}{ Total } \\
\cline { 2 - 9 } & $\mathbf{N}$ & $\%$ & $\mathbf{N}$ & $\%$ & $\mathbf{N}$ & $\%$ & $\mathbf{N}$ & $\%$ \\
\hline mechanical & 295 & $69 \%$ & 556 & $65 \%$ & 1126 & $53 \%$ & 1977 & $58 \%$ \\
\hline chemical & 75 & $18 \%$ & 141 & $17 \%$ & 456 & $21 \%$ & 672 & $20 \%$ \\
\hline electrical & 33 & $8 \%$ & 80 & $9 \%$ & 343 & $16 \%$ & 456 & $13 \%$ \\
\hline mixed & 25 & $6 \%$ & 73 & $9 \%$ & 198 & $9 \%$ & 296 & $9 \%$ \\
\hline & 428 & $100 \%$ & 850 & $100 \%$ & 2123 & $100 \%$ & 3401 & $100 \%$ \\
\hline
\end{tabular}

Smaller firms are more likely to be patenting in mechanical fields than are larger firms (Table 6). There is only a small difference in the proportions of smaller and larger firms patenting in either the chemical or electrical areas, but larger firms are - as one might expect - more likely to be patenting across more than one broad technology field.

Table 6: Firms' field of technology by firm size

\begin{tabular}{|c|c|c|c|c|c|c|}
\hline \multirow{3}{*}{$\begin{array}{l}\text { Technology field of } \\
\text { firm }\end{array}$} & \multicolumn{6}{|c|}{ Firm size } \\
\hline & \multicolumn{2}{|c|}{ Small firms } & \multicolumn{2}{|c|}{ Large firms } & \multicolumn{2}{|c|}{ Total } \\
\hline & $\mathbf{N}$ & $\%$ & $\mathbf{N}$ & $\%$ & $\mathbf{N}$ & $\%$ \\
\hline mechanical & 1604 & $62 \%$ & 371 & $46 \%$ & 1977 & $58 \%$ \\
\hline chemical & 489 & $19 \%$ & 182 & $22 \%$ & 672 & $20 \%$ \\
\hline electrical & 336 & $13 \%$ & 119 & $15 \%$ & 456 & $13 \%$ \\
\hline mixed & 153 & $6 \%$ & 138 & $17 \%$ & 296 & $9 \%$ \\
\hline Total & 2582 & $100 \%$ & 810 & $100 \%$ & 3401 & $100 \%$ \\
\hline
\end{tabular}

Notes: Nine firms are known to have ceased operations and are included only in the total count.

\footnotetext{
${ }^{23}$ For details of the US patent codes assigned to each technology field see Kingston and Scally, 2006, Appendix B (pp. 181-7).
} 


\section{Insights into Australian innovative firms}

Can these data be used to develop any meaningful insights into leading Australian innovative firms?

The dataset is dominated by firms who have only once gained a US patent. While some of these may go on to acquire further such patents, they can hardly be called technology leaders. Some of these 2,256 firms may be beginning a path of significant innovation, but the simple acquisition of one US patent does not in itself indicate this. After all, the level of inventiveness required for gaining a US patent is more akin to 'marginal difference from existing' than to 'genuine and at least modest advance' (see, for example, Lunney, 2001). A further 548 firms own two US patents but, as shown in Section 4.1 below, many of these are likely to have made only a single innovation. These findings parallel those reported by Macdonald in respect of small British firms acquiring UK patents - most firms with one patent in 1990 had acquired a second patent, but only 13 percent had more than 10 patents (Macdonald, 2003).

At the other extreme is Silverbrook with its several thousand US patents. This case, and the lessons it provides is considered below (Section 4.2).

But the most fruitful area for looking for insights to guide Australian innovation policy is among firms with two or more US patents, particularly among the small set of 224 firms which own six or more US patents (see Section 4.3 below).

\subsection{Firms with two US patents}

Another question that arises in attempting to identify groupings of innovative firms is whether those with two US patents have two genuinely different inventions, or whether these are closely related. In the domestic environment firms usually take advantage of the provisional system to lodge an initial then a final application. This is less likely to apply for overseas filings, but is nonetheless a possibility. For the 548 firms with two US patents, titles were scrutinised for similarity. Titles were absolutely identical in 20 percent of cases, and in a quarter of these cases the two patents were filed within a period of one or two years. ${ }^{24} \mathrm{~A}$ further 31 percent of firms have very similar titles, and of these two-thirds were filed within two years of each other. Overall among the firms with two US patents over half (58 percent) involved patents filed within two years of each other. These firms may be very like those firms with only one US patent - their experience of US patenting covers a narrow range of years and a narrow technology specialisation. ${ }^{25}$

A minority of firms filed their two patents at least 5 years apart: 18 per cent where titles were similar and 22 per cent where titles differed. Such firms may well have produced a genuine advance on their initial innovation. Overall 18 per cent of these firms filed five or more years apart and just six per cent filed ten or more years apart.

\footnotetext{
${ }^{24}$ That is, filed in the same calendar year or in two consecutive calendar years. For another 30 of these 113 firms the two patents were filed not more than two years apart, giving a total of 52 percent of where file dates were within two years.

${ }^{25}$ Some of the identically titled and closely filed patents may be for different inventions, but equally they may be simple variations on the theme, or extremely minor modifications. The US does have a system of terminal disclaimers where the subject matter of a second application very largely overlaps that of an earlier application, but summary data on this is not included in the BIB bibliographic information.
} 


\subsection{Silverbrook: an outlier or a model?}

This firm commenced patenting in the USA in 1998, when it claimed the SE fee for 63 of the 158 applications filed (Table 7). The percentage where the SE fee was claimed increased to 58 percent in 1999 before falling to 47 percent in 2000, then 20 percent in 2001. Since 2005 Silverbrook has not claimed the SE fee for any of its applications. It seems likely that Silverbrook passed the size qualifier for the SE fee in the early 2000s, when it owned some 760 granted US patents. While little is known about the financing of this privately owned company, it is less secretive about its patenting activities. Its website provides information about its patenting experience and takes pride in the large number of patents owned. Silverbrook employs a number of in-house patent attorneys, and some of these attend general conferences on patenting. Their target output is one patent application a day per attorney. ${ }^{26}$ The company, founded in 1994, undertakes research on small high-speed printers under the registered trade mark Memjet. ${ }^{27}$

Table 7: The Silverbrook experience: US patent applications and grants

\begin{tabular}{|c|c|c|c|c|c|c|c|}
\hline \multirow[b]{2}{*}{$\begin{array}{l}\text { File } \\
\text { year }\end{array}$} & \multicolumn{3}{|c|}{ USPTO “BIB” data } & \multicolumn{4}{|c|}{ USPTO PatFT and APPFT data* } \\
\hline & $\begin{array}{l}\text { \# SE } \\
\text { fees }\end{array}$ & $\begin{array}{l}\text { \# } \\
\text { grants }\end{array}$ & $\begin{array}{l}\% \text { with } \\
\text { SE fees }\end{array}$ & $\begin{array}{l}\text { applications } \\
\text { pending } \\
\text { from year's } \\
\text { filings }\end{array}$ & $\begin{array}{l}\text { grants } \\
\text { from } \\
\text { year's } \\
\text { filings }\end{array}$ & $\begin{array}{l}\text { total } \\
\text { filings }\end{array}$ & $\begin{array}{l}\text { \% of } \\
\text { cohort } \\
\text { granted to } \\
\text { date }\end{array}$ \\
\hline 1998 & 63 & 158 & $40 \%$ & 0 & 157 & 157 & $100 \%$ \\
\hline 1999 & 19 & 33 & $58 \%$ & 0 & 33 & 33 & $100 \%$ \\
\hline 2000 & 110 & 236 & $47 \%$ & 0 & 235 & 235 & $100 \%$ \\
\hline 2001 & 16 & 82 & $20 \%$ & 11 & 82 & 93 & $88 \%$ \\
\hline 2002 & 65 & 254 & $26 \%$ & 0 & 253 & 253 & $100 \%$ \\
\hline 2003 & 1 & 341 & $0 \%$ & 160 & 341 & 501 & $68 \%$ \\
\hline 2004 & 1 & 731 & $0 \%$ & 331 & 736 & 1067 & $69 \%$ \\
\hline 2005 & & 595 & $0 \%$ & 572 & 612 & 1184 & $52 \%$ \\
\hline 2006 & & 338 & $0 \%$ & 378 & 347 & 725 & $48 \%$ \\
\hline 2007 & & 404 & $0 \%$ & 512 & 429 & 941 & $46 \%$ \\
\hline 2008 & & 415 & $0 \%$ & 915 & 548 & 1463 & $37 \%$ \\
\hline 2009 & & 73 & $0 \%$ & 494 & 214 & 708 & $30 \%$ \\
\hline 2010 & & 6 & $0 \%$ & 490 & 72 & 562 & $13 \%$ \\
\hline
\end{tabular}

Notes: * The PatFT (granted patents database) and AppFT (published applications) databases can be found at http://patft.uspto.gov/ These databases were searched with a query to identify Silverbrook as the assignee and the year of filing (e.g. "AN/Silverbrook AND APD/1/1/2010->12/31/2010"). The resulting

\footnotetext{
${ }^{26}$ Personal discussion with Silverbrook patent attorney at a workshop on commercialising inventions (Melbourne, February 2009).

${ }^{27}$ http://www.silverbrookresearch.com/l-en/technology.html. The company website speaks more generally about Silverbrook as an "independent contract research and development company" (http://www.silverbrookresearch.com/l-en/faqs.html), and notes that the Memjet printers are produced by licensed "international companies" (http://www.silverbrookresearch.com/l-en/index.html). However there is no indication on the website of any other area of technology development. While earlier versions of their website provided details of their many patents, this information has now been moved to the separate Memjet website (http://www.memjet.com/technology/patents_research/) (Moir, 2008: 292-3). The Memjet website refers to Silverbrook as "a private, independent R\&D company based near Sydney, Australia. The company is responsible for designing and developing the core Memjet technologies and components. Silverbrook Research also qualifies component manufacturers and high-volume manufacturing processes and equipment." (http://www.memjet.com/partners/value-chain/).
} 
figures can be added to gain total filings each year and calculate the percentage of each year's filings which have been granted as at 14 June 2011. While the published applications database excludes applications with no overseas parallel, this is unlikely to apply to Silverbrook which also takes out many patents in Australia and Europe.

Gans and Hayes have noted that Australia's apparent increase in 'technological specialisation' is largely due to Silverbrook's US patenting activities, and they note that:

"While many Silverbrook patents appear to focus on small-format photo printing and mobile phone printing, the company's initial foray [into commercialisation] is instead targeting fast letter printing using a fixed print head that spans the width of the page and contains a very high number of nozzles." (Gans \& Hayes, 2010: 11)

The Silverbrook data throw light on the extent to which filing cohorts are processed within a particular time. For the early filings - from 1998 to 2002 - most applications have been fully processed. However from 2006 on less than 50 per cent had been processed as at 14 June 2011, and for 2003 to 2005 between 31 and 48 percent remained pending (Table 7). As Griliches clearly pointed out in $1990,{ }^{28}$ it is not sensible to use patent data by grant year because of the impact of administrative changes. At the same time the more valid patent data by filing year can be some five to eight years out of date.

Silverbrook operates in that area of complex electronics where strategic patenting is rife (Bessen, 2003, Hall, 2005, Hall \& Ziedonis, 2001), or, as one of their patent attorneys put it to me "we need to swap truckloads of patents". A review of some of their patents shows how trivial many of them are. These trivial patents are likely to surround and hide the core of their useful technology. Very trivial patents include such titles as Classifying an input character, Shopping system having user interactive identity and product items, Method and system for capturing a note-taking session, Method of configuring a printer for vacation periods, Method and system for instruction of a computer using coded marks, Method and system for providing insurance services and Method and system for accessing travel services.

The implications of this case for the analysis of patent data are significant - as shown in Figure 5, the whole Australian experience of patenting in the USA is changed by the behaviour of one company. Without Silverbrook the trend and volume of Australian patenting in the USA would be lower. Patent data are frequently used in high-volume quantitative analyses, where the impact of such idiosyncratic factors can easily be missed.

\subsection{Firms patenting often in the USA}

Having set aside those firms which assign all patents to overseas entities, those which have only one or two US patents, and the extreme outlier Silverbrook with its many thousands of patents, there remains a group of 597 firms with between three and 400 US patents. This divides into a set of 373 companies with just a handful of US patents (three to five), and 224 firms with at least six but less than 400. Of the 597 firms, 450 have at least one granted US patent in the most recent period (1995 or later). The remainder of the paper focuses on these 450 firms. Of these firms 37 are overseas based, four are

\footnotetext{
${ }^{28}$ Griliches:1990: 1690-3.
} 
companies where at least some patents are jointly owned by an Australian and an overseas assignee, and the remaining 409 are based in Australia.

The 37 overseas based companies are generally large global patenters. The dominant industry is electronics and software, with majors such as Canon (376), ${ }^{29}$ Cisco (119) and Alcatel (103) as well as speciality companies such as games software company Konami (8). Increasingly firms operating in the automotive and other engineering-based industries incorporate electronics into their core technology, and such firms are well represented Schefenacker Vision (37) has a core capability in car mirrors but also produces electronic components, Illinois Tools (23) is increasingly diversified and Weir Warman (34) produces equipment for the mining industry. Another major area represented is chemicals, including pharmaceuticals. ${ }^{30}$ Finally there are two packaging companies (Precision Valve Corporation (6) and Tetra Pak (4)). One outlier among these firms Multistack Inc. - was a management buy-out focusing on the US distribution of Australian designed water chillers. As such it is clearly a spin-out from indigenous Australian inventive activity, but the company and its sales is overseas based. The company website indicates recent commencement of manufacturing in the USA. ${ }^{31}$

Are the remaining set of 409 Australian based companies the core of leading innovation in Australia? There are 268 small and 141 large companies, so large companies are more frequent than in the general dataset of US patent holders. As one might expect the smaller firms hold fewer US patents - 90 percent have five or less and only ten percent more than ten, compared to 48 percent and 52 percent among large firms. As in the larger dataset, smaller firms are more likely to be operating in mechanical technologies (38 compared to 33 percent) than larger firms and are less likely to be patenting across technology fields (26 compared to 38 percent).

Those with more than 25 US patents during the period are shown in Table 8. As one would expect, this group of companies includes some very well known Australian firms which have been successful in developing and globally marketing leading edge technology. Such firms include ResMed, Orbital, Cochlear and Aristocrat. ${ }^{32}$ There are also two major companies that have developed out of the Australian subsidiary of ICI. ${ }^{33}$ Also included are well-known companies with a strong $R \& D$ competence, but operating in industries where $\mathrm{R} \& \mathrm{D}$ is not as dominant an activity as in medicine. ${ }^{34}$ Two independent companies are now owned by overseas companies - Bishop Steering and

\footnotetext{
${ }^{29}$ The figures in parentheses are the number of patents in the dataset owned by the specified company.

${ }^{30}$ Johnson \& Johnson (32), Du Pont (28), Chiron (20 - now owned by Novartis), Dow Corning (11) and Intervet and Monsanto in the agricultural chemical arena (10 and 7).

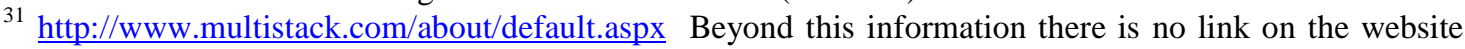
back to the original Australian company. Further there is no indication of a continued relationship, with Multistack Inc claiming itself to be a leading innovator not an imitator.

32 Another well-known Australian company fitting this designation is Gene Shears, which has only 24 US patents so does not fit the criteria for Table 8. Gene Shears is a spin-out from CSIRO, the major publiclyfunded research institute in Australia. It is an unlisted company and while information is available on the original technological invention, it is difficult to obtain information about its performance. As a subsidiary of CSIRO, Gene Shears is a small company. It has never, however, claimed the SE fee for its US patents.

${ }^{33} \mathrm{http} / / /$ www.orica.com/BUSINESS/COR/orica/COR00254.nsf/Page/About_OricaHistory

34 It is notable that these companies are dominated by mining - BHP and Rio Tinto are major players in diversified mining activities and James Hardie is a fibre cement maker. But this groups also includes Telstra - a telecommunications service company.
} 
Mount Isa Mines (MIM). Finally there are two companies about which no useful information can be found. ${ }^{35}$

\section{Technology-led successes}

Australia has a number of successful start-ups in medical technology and pharmaceuticals and several of these feature in this dataset.

Table 8: Australian-based companies, last patenting since 1994, with >25 US patents

\begin{tabular}{|c|c|c|c|c|c|}
\hline Company & $\begin{array}{c}\text { \# US } \\
\text { patents }\end{array}$ & Size & Tech field & $\begin{array}{c}\text { Assign- } \\
\text { ment }\end{array}$ & $\begin{array}{c}\text { Fee } \\
\text { strategy }\end{array}$ \\
\hline \multicolumn{6}{|l|}{ Technology-led success stories } \\
\hline ResMed & 216 & $\mathrm{~L}$ & mixed & All AU & change \\
\hline Orbital & 125 & L & mechanical & All AU & na \\
\hline Cochlear & 85 & L & mixed & All AU & change \\
\hline Aristocrat & 77 & L & mechanical & All AU & na \\
\hline AMRAD (Zenyth) [now Merck] & 45 & $\mathrm{~S}$ & chemical & All AU & mixed \\
\hline CSL & 42 & L & chemical & All AU & na \\
\hline F. F. Seeley & 42 & S & mixed & All AU & mixed \\
\hline Biotech Australia [now 3M] & 39 & L & chemical & All AU & na \\
\hline Memtec & 34 & L & chemical & mixed & no \\
\hline Metal Storm & 33 & S & mechanical & All AU & mixed \\
\hline Arana Therapeutics [now Cephalon] & 31 & S & chemical & All AU & $\mathrm{C}$ \\
\hline AMBRI & 26 & L & chemical & All AU & na \\
\hline \multicolumn{6}{|c|}{ Australian offshoots of global companies } \\
\hline Orica & 265 & L & mixed & mixed & na \\
\hline Dulux Australia & 35 & $\mathrm{~L}$ & chemical & All $\mathrm{AU}$ & na \\
\hline \multicolumn{6}{|l|}{ Large Australian companies } \\
\hline BHP & 166 & L & mixed & All AU & na \\
\hline Rio Tinto & 72 & L & mixed & All AU & error \\
\hline Telstra & 46 & $L$ & mixed & All AU & na \\
\hline James Hardie & 44 & L & mixed & mixed & na \\
\hline Amcor & 34 & L & mixed & All AU & na \\
\hline Bluescope Steel & $27+25.5$ & $\mathrm{~L}$ & mixed & mixed & na \\
\hline \multicolumn{6}{|c|}{ Australian companies taken over by overseas companies } \\
\hline Bishop Steering & 51 & $\mathrm{~L}$ & mixed & All AU & na \\
\hline Mount Isa Mines (Xstrata) & 28 & $\mathrm{~L}$ & mixed & All AU & na \\
\hline \multicolumn{6}{|l|}{ Other } \\
\hline Technological Resources & 88 & L & mixed & All AU & na \\
\hline Kinetic & 25 & $\mathrm{~S}$ & mixed & All $\mathrm{AU}$ & mixed \\
\hline
\end{tabular}

\footnotetext{
35 Kinetic Limited has 25 US patents in the area of vehicle suspension systems, filed 1993 to 2005. Technological Resources has 88 patents filed 1993 to 2009 in the minerals/minerals processing area. Partly because of their names it has not been possible to find information about them except about their patents.
} 
ResMed was a 1989 start-up based on technology developed at the University of Sydney for a device for treating obstructive sleep apnoea. ${ }^{36}$ It now has 216 US patents and 84 registered trade marks. ResMed would have benefited substantially from R\&D grants and tax concessions in its early years. In its early years it sought the SE fee for its US patents, but has not done this since 1998. While still listed on the Australian stock exchange, it is also now listed on the New York Stock exchange and has moved its investor information from its Australian to its US website. It now has over 3,000 employees, about a third located in Australia. ${ }^{37}$ ResMed has more granted patents in the USA than in Australia. ${ }^{38}$

Cochlear has a similar story - it filed its first US patent in 1985 and claimed the SE fee for all patents filed before 1999. During its early years Cochlear benefited substantially from Australian government R\&D support programs, and use of this support continues today. ${ }^{39}$ By 2010 Cochlear was reporting 2,239 employees worldwide, and reinvestment of 13 percent of its revenue in $\mathrm{R} \& \mathrm{D}$. Cochlear recognises the importance of patents and in its 2010 report noted that it had more than 850 patents pending or granted worldwide. Much of Cochlear's manufacturing and R\&D activities remain in Australia though it also manufactures in Sweden. ${ }^{40}$

Arana Therapeutics ${ }^{41}$ was a small Australian company operating in the antibody therapeutics sector. ${ }^{42}$ Arana had licensing agreements with a number of major pharmaceutical companies and when it was acquired by US-based Cephalon in 2009, Cephalon advised that it anticipated those royalties would offset the costs of development in the near term. ${ }^{43}$. At the time of acquisition Cephalon announced it anticipated advancing Arana's pipeline of products in inflammatory diseases and cancer. It is not possible from Cephalon's website to establish whether the Arana facility in NSW still exists following the purchase, though Cephalon does maintain an Australian subsidiary. ${ }^{44}$ Over the period 1993 to 2007 Arana acquired 31 US patents. While it remained small (70 employees) until its acquisition by Cephalon, Arana had a mixed strategy of claiming the SE fee, and ceased doing so only in 2001. This may have been because of its licensing agreements with major players such as Abbott Laboratories and Johnson \& Johnson.

\footnotetext{
${ }^{36} \mathrm{http}: / /$ www.resmed.com/uk/about us/history.html?nc=aboutus

37 "As of June 30, 2010, we had approximately 3,200 employees or full time consultants, of which ... 400 in research and development... Of our employees and consultants, approximately, 1,300 were located in Australia..." ResMed 2010 Annual Report (http://investor.resmed.com/phoenix.zhtml?c=70291\&p=irolreportsAnnual).

${ }^{38}$ A search of AusPat on 5 July 2011 shows ResMed has 191 Australian patents which have ever been accepted or sealed (of which 62 have lapsed or ceased).

${ }^{39}$ Unfortunately the Australian government does not make public the amount of R\&D support provided to companies nor who the beneficiaries are. Likewise companies do not provide information on this in their annual reports. Even the government's major 1995 enquiry into R\&D support programs provided only very rules-based information on R\&D support, with no information on specific beneficiaries (Productivity Commission, 1995).

${ }^{40}$ http://www.cochlear.com/corporate/annual-reports

41 Previously named Peptech Limited and Peptide Technology Limited

${ }^{42} \mathrm{http}: / / \mathrm{www}$. biotechnology.nsw.gov.au/sectors.aspx? sectorid=7\&companyid=1645.

${ }^{43}$ http://investors.cephalon.com/phoenix.zhtml?c=81709\&p=irol-newsArticle\&ID=1290449\&highlight

${ }^{44}$ Cephalon itself was only founded in 1987 but is now a large (3,000 employee) company which is a member of both Fortune 1000 and the S\&P 500 Index (http://investors.cephalon.com/phoenix.zhtml?c=81709\&p=irol-newsArticle\&ID=1290449\&highlight= ).
} 
Like ResMed, Cochlear and Arana, AMRAD (now Zenyth) ${ }^{45}$ is one of Australia's medical research success stories. This small company was formed by four leading edge medical research institutes in 1986, but was delisted from the Australian Stock Exchange in 2006 following its take-over by CSL. ${ }^{46}$ It was subsequently sold off to Merck. CSL itself is a rather different story from ResMed, Cochlear and AMRAD - it originated in the privatisation of a government vaccines and serum facility. The privatised CSL has performed well, and as noted here has expanded through take-overs of successful startups like AMRAD as well as organic growth.

Orbital is an interesting innovation story, perhaps not well known outside Australia. Orbital's basic technology is disruptive, and the firm faced many challenges in trying to commercialise its inventions. The initial orbital engine used only one triangular shaped piston to create five combustion chambers, and attracted substantial interest and support. In the end, however, the technology was unable to compete against normal car engines. However application of the sophisticated fuel-injection and combustion system developed for the orbital engine to two-stroke engines was commercially successful. ${ }^{47}$

Aristocrat is also very different - it produces gambling machines, originally specialising in slot machines (better known as 'one-arm bandits' or 'fruit machines'). Aristocrat has had a roller-coaster ride in terms of its performance as a company, though it ranks second globally in the slot machine line of business. ${ }^{48}$ Aristocrat has expanded from its slot machine base into software games, so can be considered to be part of the electronics and computing sector.

The Australian Membrane and Biotechnology Research Institute (AMBRI) was associated with the University of Sydney, and was registered as Australian Membrane Technologies Pty Limited. According to NSW government information, the company was established "to commercialise a novel nano-particulate membrane bioreactor technology (the "NMB") with a wide range of applications, in particular, waste water treatment and recycling." The central technology is a membrane which efficiently aerates organic matter in waste streams. The company was granted 26 US patents filed between 1991 and 2001. It appears, however, that the company no longer exists, and as it was privately held public sources on take-overs do not indicate its fate. ${ }^{49}$

Memtec was an Australian start-up - a spin-out from the University of New South Wales - which made use of government R\&D grants in its early years. The original patent was taken out by UNSW covering an innovative polyamide low pressure filtration membrane. It became a public company in 1983 and listed on the ASX in 1984. One of its patent attorneys provided evidence to an Australian parliamentary committee in 2005

\footnotetext{
${ }^{45}$ Acronym for Australian Medical Research and Development Consortium Limited. It changed its name to Zenyth Therapeutics in 2005 (http://www.eoas.info/biogs/A002012b.htm).

${ }^{46} \mathrm{http}: / / \mathrm{www} . d e l i s t e d . c o m . a u / C o m p a n y / 9490$

${ }^{47} \mathrm{http} / / / \mathrm{www}$. powerhousemuseum.com/australia_innovates/?behaviour=view_article \&Section_id=1020\&article_id=10041 ${ }^{48}$ http://en.wikipedia.org/wiki/Aristocrat_Leisure

49 Links from the NSW government site (http://www.biotechnology.nsw.gov.au/alphabetical.aspx? letter=a\&companyid=1698) to the company no longer work. No information could be found on the current University of Sydney website, except for the 2004 University of Sydney Annual Report where its name is given in a list of centres. The Australian Department of Foreign Affairs and Trade gives publicity to AMBRI in the context of nano-technology to be used for biosensors, but provides no links to the source material (http://www.dfat.gov.au/facts/sci_achv.html).
} 
suggesting, inter alia, that take-up of this new technology in Australia was poor. ${ }^{50}$ Memtec established a US subsidiary and in early 1998 was taken over by US-based Pall Corporation. ${ }^{51}$ All patents filed from 1984 to early 1995 are assigned to the Australian Memtec entity, but from May 1995 the remaining four patents are assigned to Memtec's US subsidiary. Memtec never claimed the SE fee. No Australian-invented US patents have been granted from filings since mid 1996. This suggests that the R\&D expertise located in Sydney has either moved to the new US venue or has been disbanded following take-over by Pall Corporation. The word Memtec is not on the Pall Corporation website. ${ }^{52}$ No Pall Corporation US patents with an Australian inventor could be found.

Biotech Australia undertook much of its R\&D jointly with universities and/or CSIRO. Its core technology, released in 1990, was an innovative screening test for detecting Salmonella which substantially reduced the waiting period for results. It was manufactured and marketed worldwide by Biotech's Tecra Diagnostics division. It won the 1992 Australian Food Industry Innovation Award. Subsequently the company launched a test for Listeria in food. ${ }^{53}$ Little information is available on the change from Biotech to Tecra International as this was a private buy-out by management. Tecra became part of the Biotrace International Group in 2004 and was then acquired by $3 \mathrm{M}$ in late 2006. Tecra continues to manufacture rapid test kits for major causes of food borne illness as well as test kits for toxins and allergens. ${ }^{54}$

Seeley International (F. F. Seeley Nominees) has 42 US patents acquired between 1982 and 2009. Ten of its 42 US patents are defined as chemical though they concern evaporative cooler systems and fire retardants; four are defined as electrical, concerning switches and leads; and the remaining 28 are mechanical, again largely in the area of evaporative coolers. Originating in Adelaide in 1972, after developing an all-plastic evaporative air conditioner, Seeley began exporting in the 1980s. In the 1990s Seeley acquired Braemar, Coolair and Tudor, expanding its product range to heating and cooktops. Seeley International remains a small enterprise, employing just 300 people. ${ }^{55}$ It has claimed the SE fee on all but two of its US patents.

Metal Storm, founded in 1994, was based on the development of technology allowing stacking of rounds for weapon systems. It listed on the ASX in 1999 expanding to take on US government contracts. The company owns 33 US patents filed between 1998 and 2008. It has sought the SE fee on just four of these. In Australia it has filed 57 standard patent applications in the period since 1994, and 13 of these are currently in force, including the original "a barrel assembly".

Of these 12 companies which grew from small beginnings on the back of solid technological innovation, five are in the medical area. The others are quite diverse in terms of their technology. Seven are now classified as large companies, though some became large as a result of being taken over. Three of the twelve companies are now owned by overseas entities. The meaning of this change of ownership for the location of

\footnotetext{
${ }^{50} \mathrm{http} / / / \mathrm{www}$. aph.gov.au/house/committee/scin/pathways/subs/sub42.pdf

${ }^{51}$ http://www.delisted.com.au/Company/5318/MEMTEC\%20LIMITED

52 http://www.pall.com/.

$53 \mathrm{http}: / /$ apc-online.com/twa/agriculture $2 . \mathrm{html}$

${ }_{54}$ Email advice from $3 \mathrm{M}$ in response to query about $3 \mathrm{M}$ acquisition of this company.

${ }^{55} \mathrm{http}$ ///www.seeleyinternational.com/en/about-us/history
} 
their leading edge R\&D activities is unclear. At least half of these companies have commenced from research undertaken in universities or research institutes.

\section{Offshoots of overseas companies}

Originally the Australian subsidiary of ICI ${ }^{56}$ a major UK chemicals company, Orica was spun off in 1997 when it changed its name. It divested its Dulux paint interests to focus on services to the mining, construction and infrastructure industries. Between 1971 and 2007 it acquired 265 US patents. The great majority of these were assigned to its Australian entity, with just 12 percent assigned to the British parent company. The chemical industry involves substantial teamwork in research. Among the 234 patents assigned to the Australian subsidiary just 14 involve non-Australian residents in the research team. But among the 31 assigned to the UK, 25 involve non-Australian inventors. This suggests that the location of the research activity of those patents assigned overseas may well have been overseas, with some subsequent movement of research staff. As noted, Dulux Australia was part of ICI's Australian subsidiary but after this became independent, the Dulux Group was spun out as a separate company. Dulux Australia includes Balm Paints which started in Sydney in 1918.

\section{Large Australian companies}

BHP - "the Big Australian" - remains an iconic Australian company despite its 2001 merger with Billiton to become the global resource giant BHP Billiton. It remains listed on the ASX with the code BHP, with a secondary listing on the London stock exchange. Since 1972 BHP has obtained at least one US patent every year, with the latest issued patents being five granted from filings in 2007. This contrasts with another large Australian metals company, Bluescope Steel. Bluescope was formerly a business division of BHP and has produced several important inventions including Colorbond in 1966; a zinc-aluminium product developed in the mid 1970s jointly with a US steel company and a thin strip casting process developed in partnership with Ishikawajima-Harima Heavy Industries of Japan. ${ }^{57}$ This dataset includes 51 jointly owned Bluescope/Ishikawajima patents as well as the 27 owned by Bluescope. Indeed all Bluescope US patents since 1993 and jointly owned with Ishikawajima. While Bluescope has a number of significant innovations, as a smaller company it patents less frequently than BHP.

Rio Tinto is another diversified resource giant whose major operations are in Australia and Canada. It has headquarters in London and Melbourne. Like its rival BHP, Rio has dual stock exchange listing in both the UK and Australia. ${ }^{58}$ While BHP has 165 US patents filed in the period 1972 to 2007, Rio has 72 filed in the period 1973 to 2001. Either subsequent filings from Rio are very delayed at the USPTO or Rio has ceased actively patenting in the USA, at least where Australian resident inventors are concerned. Both companies patent across a range of technology classes though Rio's patents are

\footnotetext{
${ }^{56}$ In fact it was originally an explosives supplier to the Victorian goldfields, but then became part of Nobel and subsequently ICI (http://en.wikipedia.org/wiki/Orica)

57 http://www.bluescopesteel.com/go/about-bluescope-steel/our-history/history-of-bluescope-steel/historyof-bluescope-steel\#2

${ }^{58}$ http://en.wikipedia.org/wiki/Rio_Tinto_Group
} 
more heavily concentrated in the chemicals area (three-quarters) while BHP has just over 40 per cent in each of chemicals and mechanics and the remaining in electrical areas.

The third resource-based company here is James Hardie, a fibre cement manufacturer. This company is unusual in that is has moved its headquarters twice after a very long period as a major established Australian company. Its strong Australian base remains evident in the fact that it is still listed on the ASX. The first move - in 2001 to the Netherlands - occurred following legal action on behalf of former employees regarding asbestos-related occupational injuries. In 2010 James Hardie moved its headquarters to Ireland. These moves are possible because James Hardie makes substantial use of the parent/subsidiary company structure option. The assignment of nationality in its patent holdings largely follows these corporate headquarter relocations: all patents filed before 2000 are assigned to an Australian subsidiary, all patents filed since 2005 are assigned to an Irish entity, and all filings between 2001 and 2004 patents are assigned to either Australian, Dutch or Irish entities. It seems probable that all future James Hardie patents will be assigned to their Irish entity.

Telstra is the privatised Australian phone company comprising former publicly owned domestic and overseas telecommunications companies. Because of this base it remains dominant in the Australian landline market as the original competitor had as its core only the small satellite company AUSSAT. Other companies have made more substantial inroads into the mobile market which is much more competitive than the landline market. Seventeen of Telstra's 46 US patents date from the pre-1993 public ownership period.

Amcor is a major Australian pulp and paper manufacturer operating in the global packaging industry, like its rival the privately owned Visy. It is now among the global top 1,000 companies. ${ }^{59}$ Amcor owns 34 US patents obtained in the period 1974 to 2003. This is substantially more than the ten owned by Visy.

\section{Australian companies taken over by overseas companies}

As noted above a number of companies discussed under the heading of technology-led success stories have been taken over by overseas company - AMRAD by Merck, Biotech Australia by $3 \mathrm{M}$, Memtec by Pall Corporation and Arana Therapeutics by Cephalon. ${ }^{60}$ Two rather larger Australian companies have had similar experiences - Bishop Steering and Mount Isa Mines (MIM). MIM was taken over by Xstrata in 2003, a take-over which led to Xstrata doubling in size. Of the patents in the dataset now owned by Xstrata, 23 out of 28 are in the name of Mount Isa Mines. ${ }^{61}$

In early 2011 Bishop Steering was taken over by Georgsmarienhütte Group. ${ }^{62}$ As the name implies, Bishop's speciality is vehicle steering systems, and it acquired 51 US patents in the period 1988 to 2005 . According to the press release issued by its new owner, Bishop actively licensed its technology to manufacturers of steering gears and

\footnotetext{
${ }^{59}$ Seehttp://www.amcor.com/about_us/company/about_history.html andhttp://en.wikipedia.org/wiki/Amcor

${ }^{60}$ Another technology-led success story, Memtec, was discussed above under the heading companies with mixed Australian/overseas assignment.

${ }^{61}$ Four are owned by Xstrata Queensland Ltd and one by Xstrata Copper Exploration Pty Ltd.

${ }^{62} \mathrm{http}: / / \mathrm{www} . \mathrm{gmh}-\mathrm{gruppe} . \mathrm{de} / \mathrm{uk} / \mathrm{search} . \mathrm{html}$
} 
components: "BISHOP has over 250 patents and patent applications in 17 countries as well as numerous licensees worldwide." At the time of the takeover the Bishop companies in Australia, the USA and Germany employed 16 engineers and 30 production staff. This suggests the Australian operations are small but highly technical.

\section{Overall picture}

Genuinely Australian companies which actively use the US patent system are clearly a very diverse set. While attention here has focused on those companies making more frequent use of the US patent system, the diversity among those with somewhat fewer US patents is also striking - they too cover a very wide range of industries and firm sizes. The development of commercially valuable new technology has occurred across a wide range of products and technologies, and while university and research institute spin-outs do feature they are not by any means the major pattern for such innovative companies.

Beyond that, with the data available from this particular source, and the lack of any clear identifier for cross-matching data to other sources, it is not possible to develop a useful typology of innovative firms. Nonetheless some pointers suggest useful lines of study for innovation policy purposes. For example, to what extent is it relevant to policy makers if innovative local firms are sold to overseas owners? Does this matter only if a consequence is the subsequent move of $\mathrm{R} \& \mathrm{D}$ activity or high-technology manufacturing? As seen here, some innovative firms can be sold more than once, for example Sola and AMRAD. Where innovative domestic firms grow substantially, as for example in the case of ResMed or Cochlear, does the company base 'stick' in Australia, or might it in fact make the move overseas?

\section{Conclusions and next steps}

\subsection{Data issues}

This analysis presented in this paper shows that it is possible to use the USPTO BIB data series to investigate firm ownership of patents on a national basis. However the data are quite 'dirty' for this purpose and require substantial scrutiny and cleaning. Though tedious, this provides rewards in terms of a deeper understanding of the complexity and nuances of using patent data as a simple indicator of anything to do with technology.

There are several small changes that would substantially increase the ease of use of these data without detracting from their richness. The first and simplest would be for the USPTO to recognise the reality and importance of the assignee variable and include more elements from this - particularly country code - in the dataset they sell. The assignee country code is very important for policy research purposes.

As noted above there are reasons to believe that the inventor country code is a mix of residence at time of grant and residence at time of filing. The latter is likely to provide a solid and meaningful picture of the location of patentable inventive activity at any point in time. It can therefore be useful for industry and technology policy advisors. However, country of residence of an inventor at the time of grant - given that between two and seven years are likely to have elapsed - is a rather confused variable. It might be of use at 
the instant of grant, providing a snapshot then of where past inventors are currently located. But the meaning of such data will not survive over time.

In their earlier analysis Kingston and Scally used first listed inventor to uniquely assign USPTO-issued patents by country. In this analysis patents have been selected from the BIB database on the basis of any inventor being Australian. Among firms which assign some or all of their patents overseas there are a higher proportion of patents where the Australian inventor is not the first inventor. But overall, among the firms where any assignment was to an Australian entity, the first inventor was an Australian resident in 97 per cent of cases. This contrasts with cases where all patents were assigned to nonAustralian entities where only 63 per cent of first inventors were Australian residents.

More generally, it would be useful if patent offices across the world would recognise that asking for company identifier numbers is now standard practice in most government administration. For example the Australian Bureau of Statistics uses a company's Business Number to track it through its Business Longitudinal Database. ${ }^{63}$ Such standard identifiers would make it easier to match data for the same company within and between datasets. In analysing patent data it is preferable to have information about the characteristics of the company so matching across datasets is an important facility.

\subsection{Innovating firms}

What can these data tell us about innovating firms? The simple answer is that, on their own, patent data provide only limited insights into innovative behaviour. The dataset is dominated by the 66 percent of firms who have only one US patent. To this group should be added many of the firms with two US patents where the patents either had very similar titles or were filed within two years of each other. If such firms are treated like one-off patenters, then fully 2,676 of the 3,401 firms provide little insight into globally leading innovation. This is not to say that these firms might not include firms which may take off. Certainly there are small start-ups in the list, such as Dyesol, but these are as yet still very much in the early phase of developing their products. This leaves just 725 firms which might provide insights into innovative behaviour among Australian firms.

As noted above the variables available in a patents-only dataset are insufficient for any complex analysis. As an alternative those domestic firms with a reasonable degree of experience in patenting in the US were scrutinised and this showed a wide diversity both in terms of the types of companies patenting and in their subsequent business experience. The data show Australia's competence in research based on the life sciences, with a number of notable successes, some of which have been taken over and some of which have remained independent. They also show that larger established firms in the resources and telecommunications sectors appear to be holding their own in terms of patentable technological developments.

While the number of patents obtained varies considerably between these firms, there is one stand-out case - Silverbrook Research Pty Ltd. This company has developed very small high-speed printing technology, and surrounds its core technology with thousands of peripheral (and extremely trivial) patents. While this is unique in Australia it is common practice in the electronic industries with which the firm competes. As a

${ }^{63}$ http://www.abs.gov.au/AUSSTATS/abs@.nsf/Lookup/8166.0Explanatory\%20Notes12009-10? OpenDocument 
consequence this firm's behaviour is unlikely to provide any relevant learning for firms in industries where there are fewer games played around the patent system.

A final finding of interest in this Australian case is that in a medium sized economy the outlier behaviour of even one firm can radically affect overall national figures and their interpretation. Here Silverbrook, with its 3,666 US patents, has a marked effect on both the volume and pattern of Australian patenting in the USA. This suggests that, at least in Australia, US patent data as a proxy measure for technological innovation should be treated with great caution. 


\section{References}

Bessen, J. E. (2003) Patent Thickets: Strategic Patenting of Complex Technologies, available at SSRN: http://ssrn.com/abstract=327760 or doi:10.2139/ssrn.327760

Blind, K., Edler, J., Frietsch, R. \& Schmoch, U. (2003) "Scope and Nature of the Patent Surge: A View from Germany", in OECD (Ed.) Intellectual Property Rights (IPR), Innovation and Economic Performance. Paris, OECD.

Blind, K., Edler, J., Frietsch, R. \& Schmoch, U. (2006) "Motives to Patent: Empirical Evidence from Germany", Research Policy, 35(5), 655-672.

Gans, J. S. \& Hayes, R. (2009) Assessing Australia's Innovative Capacity: 2008 Update. Melbourne, Intellectual Property Research Institute of Australia (IPRIA).

Gans, J. S. \& Hayes, R. (2010) Assessing Australia's Innovative Capacity: 2009 Update. Melbourne, Intellectual Property Research Institute of Australia (IPRIA).

Griliches, Z. (1990) "Patent Statistics as Economic Indicators: A Survey", Journal of Economic Literature, 28(4), 1661-1707.

Hall, B. H. (2005) "Exploring the Patent Explosion", Journal of Technology Transfer, 30(1-2), 35-48.

Hall, B. H. \& Ziedonis, R. H. (2001) "The Patent Paradox Revisited: An Empirical Study of Patenting in the U.S. Semiconductor Industry, 1979-1995", RAND Journal of Economics, 32(1), 101-128.

Jaffe, A. B. \& Lerner, J. (2004) Innovation and its Discontents: How Our Broken Patents System is Endangering Innovation and Progress, and What to Do About It, Princeton: Princeton University Press.

Kim, J. \& Marschke, G. (2004) "Accounting for the Recent Surge in U.S. Patenting: Changes in R\&D Expenditures, Patent Yields, and the High Tech Sector", Economics of Innovation and New Technology, 13(6), 543-558.

Kingston, W. \& Scally, K. (2006) Patents and the Measurement of International Competitiveness, Cheltenham UK, Northampton MA: Edward Elgar.

Kortum, S. \& Lerner, J. (1999) "What is Behind the Recent Surge in Patenting?" Research Policy, 28(1), 1-22.

Lunney, G. S., Jr. (2001) "E-Obviousness", Michigan Telecommunications Technology Law Review, 7(363-422.

Macdonald, S. (2003) "Bearing the Burden: Small Firms and the Patent System", The Journal of Information, Law and Technology (JILT), 2003 (1).

Moir, H. V. J. (2008) Do Patent Systems Improve Economic Well-Being? An Exploration of the Inventiveness of Business Method Patents. PhD dissertation, Australian National University (http://papers.ssrn.com/sol3/papers.cfm?abstract_id=1423248).

Productivity Commission (1995) Research and Development: Industry Commission Inquiry Report. Report for Productivity Commission (Canberra). 


\section{Acronyms}

Apparent acronyms used in this paper and not listed here are company names.

AMBRI The Australian Membrane and Biotechnology Research Institute

ASIC Australian Securities \& Investments Commission

ASX The Australian Securities Exchange

AUSSAT AUSSAT was the government-owned communication satellite that was sold to Optus to form part of the original second telecommunications operator when the telecommunications sector was privatised.

CSIRO Commonwealth Scientific and Industrial Research Organisation

MIM Mount Isa Mines

SE small enterprise

USPTO United States Patent and Trademark Office

AusPat available at http://www.ipaustralia.gov.au/auspat/index.htm is a searchable database of Australian patents

Patent country codes

AN Netherlands Antilles

HK Hong Kong

AU Australia

IE Ireland

CA Canada

JP Japan

$\mathrm{CH}$ China

NL Netherlands

DE Germany

SE Sweden

FR France

US USA

GB United Kingdom 